\title{
PERCEIVED PHYSICAL ACTIVITY BENEFITS AND BARRIERS IN SEDENTARY ADULTS
}

\author{
Ieva Eva Skrebutėnaitė, Diana Karanauskienė \\ Lithuanian Sports University, Kaunas, Lithuania
}

\begin{abstract}
Background. Research aim was to analyse the perceptions of benefits and barriers of physical activity in physically inactive adults.

Methods. Research methods were individual interviews and qualitative content analysis.

Results. Insufficiently physically active adults have many different health and emotional problems, but this is not a sufficient motive for them to be physically active. Research participants positively evaluated the benefits of physical activity if their physical activity did not exceed their physical fitness; however, it was not optimal and did not comply with the proposed minimum recommendations. Physical activities of adults were mostly related to holidays, cooking, playing with children, and activities in nature. Meanwhile, respondents were more physically inactive - working at home, reading books, and spending time on smart devices. Adults mentioned more reasons to be physically passive than active. Internal causes of physical inactivity were related to lack of time, lack of motivation, antipathy to sport, health problems and internal beliefs, external causes - workload, weather conditions, financial situation, family and household.

Conclusions. Physical health problems and psychological ailments of inactive adults were frequent consequences of physical inactivity. Their activities after work were passive (working at home, reading books and time on smart devices) and active (holidays, cooking, playing games with children, activities in nature). Although there were more active activities, most of them were in leisure time and they did not fully meet the minimum recommendations. The participants positively evaluated the benefits of physical activity if their physical activity did not exceed their physical fitness. Internal causes of physical inactivity of the participants were lack of time, lack of motivation, antipathy for sport, health problems, feeling of loneliness and age, external causes - workload, weather conditions, financial situation, family and household.
\end{abstract}

Keywords: physical inactivity, benefits of physical activity, obstacles, adults.

\section{INTRODUCTION}

$\mathrm{M}$ ost people are conscious of the importance of physical activity for health, but physical inactivity remains a major public health problem worldwide. Healthy lifestyle and exercise have been shown to be an effective tool for adults who want to reduce body weight and improve overall health (Caron et al., 2017). Exercise can strengthen muscle tone and increase physical fitness as well as endurance. Current national recommendations for aerobic exercise suggest that every week adults have at least 150 minutes of moderate intensity and at least
75 minutes of intensive aerobic exercise. The World Health Organization (WHO) recommends adults to do health-enhancing exercises in a variety of activities during their leisure time, and in particular outdoor exercise such as cycling, walking, or Nordic walking. Aiming at strengthening the heart and the respiratory function, muscle strength and endurance, stiffness and firmness of bones, improving the overall functional health of the body, and reducing the symptoms of anxiety in this age group, it is recommended to exercise the main (large) muscle groups at least twice a week (WHO, 2016). 
Although society aims to promote physical activity and promote its benefits, it has been observed that physical inactivity is gradually increasing and thus remains a health problem in the society. There are various reasons why many adults refuse active leisure time or other physical activity. The reasons include lack of motivation, time and, of course, self-confidence (Herazo-Beltrán et al., 2017). In many studies, physical inactivity is identified as one of the most important factors contributing to the global increase in health problems in Europe and worldwide. Therefore, there is a high likelihood of developing non-communicable diseases, cancer, cardiovascular diseases, and type II diabetes. Researchers have found that physical activity is a great preventive measure to protect one's health from various diseases (Maheri et al., 2017).

Many people seem to have sufficient knowledge of physical activity and its benefits, but research shows that the vast majority of people in the society do not engage in physical activity, which contributes to an increase in global health risk. The World Health Organization reports that 3.2 million people in the world die each year due to their physical inactivity (WHO, 2016). The prevalence of physical inactivity was established to be highest among 3049 year-old persons, with women (28.9\%) showing higher physical inactivity than men (22.6\%) (Thanamee et al., 2017). Therefore, the study aims to answer the problem question: what are the sedentary adults' perceived benefits of and barriers to physical activity. The answer to this question will help motivate sedentary adults and engage them in physical activity. Research objectives include the analysis how sedentary adults describe and evaluate their physical and mental health, what leisure time activities they choose, what benefits of physical activity they see, and what prevents them from being physically active.

\section{METHODS}

The qualitative study was carried out following the principles of the grounded theory. Grounded theory is a research methodology concerned with the generation of theory, which is 'grounded' in data that has been systematically collected and analysed. It is used to uncover such things as social relationships and behaviours of groups, known as social processes (Noble \& Mitchell, 2016).

Research participants were selected using the criterion sampling method. Criterion sampling involves selecting cases that meet some predetermined criteria of importance (Patton, 2001). The study involved the persons who met the following criteria:

- 35 years of age and older (people of this age are expected to have a family, children, and a steady income);

- higher education (having information on the benefits of physical activity and the damage of physical inactivity);

- sedentary occupation (working in an educational institution; they are expected to have income for organized active physical activity in a sports club or using a variety of sports inventory);

- persons not physically active enough (not engaged in physical activity every day, not athletes, rarely visiting a sports club).

Thus, the study involved people who work being sedentary for long time, do not change the environment and suffer from routine and physical inactivity.

The sample size was determined based on the saturation principle, i. e. the interviews were stopped when no new responses were received (Francis et al., 2010). Thus, 12 sedentary adults participated in the study. Among them there were 4 men and 8 women, aged 35 to 49 years, living in Vilnius and working at a university of applied sciences. A more detailed description of the participants is given in Table 1, which also includes age, gender, position, and family status.

Participants were interviewed at the workplace in the University Administration Office. During the study, a neutral environment was created, nobody disturbed, and the same questions were given to each interviewee. Non-verbal communication was also taken into account.

The interview guide involved questions about the quality of life, physical activity benefits and obstacles, and related questions. The interviews took place in January-February, 2019. The interview with each person was recorded and later transcribed. The responses were systematized and analysed.

The data were analysed using the method of content analysis. Content analysis is a research technique used to make replicable and valid inferences by interpreting and coding textual material (Duriau, Reger, \& Pfarrer, 2007).

Research ethics. When investigating human behaviour, the researcher intervenes in a private 
leva Eva Skrebutènaitè, Diana Karanauskienè

PERCEIVED PHYSICAL ACTIVITY BENEFITS AND BARRIERS IN SEDENTARY ADULTS

\begin{tabular}{|l|c|l|l|}
\hline \multicolumn{1}{|c|}{$\begin{array}{c}\text { Research } \\
\text { participant* }\end{array}$} & Age & \multicolumn{1}{c|}{ Position } & \multicolumn{1}{c|}{ Family status } \\
\hline Evelina & 36 & University teacher & Married with two children \\
\hline Audronė & 37 & University teacher & Married with one child \\
\hline Viktorija & 48 & University accountant & Married with two children \\
\hline Aušrine & 35 & University administrator & Single with no children \\
\hline Aukse & 39 & University marketing representative & Married with two children \\
\hline Giedrius & 46 & University teacher & Married with three children \\
\hline Laima & 36 & University teacher & Divorced with one child \\
\hline Lukas & 42 & University teacher & Divorced with no children \\
\hline Julius & 48 & University teacher & Married with one child \\
\hline Agne் & 46 & University teacher & Divorced with two children \\
\hline Ksenija & 35 & University teacher & Engaged with one child \\
\hline Gintas & 49 & University teacher & Married with two children \\
\hline
\end{tabular}

Table 1. Characteristics of research participants

Note. Research participants' names were changed.

life, so in qualitative research, first and foremost, the welfare of the research participants is taken care of, and thus the form of informed consent was provided before the study. In order to ensure the confidentiality of research participants, the interview was carried out in accordance with the requirements of the laws of the Republic of Lithuania

The data received were analysed according to the principle of impartiality, trying to investigate the phenomenon without any bias. In order to ensure the transparency of the research, the insights made in the study were illustrated by literal quotations from interview transcripts. All research data was stored to avoid negative consequences for the individuals involved and unauthorized access.

\section{RESULTS}

Physical and psychological health of research participants. Aiming at assessing the psychological health of sedentary adults, the participants were asked if they often experienced fluctuations of mood and stress. Respondents were confident that they were often confronted with difficulties, especially when performing job functions. They argued that bad mood was inevitable when something went wrong at work or conflicts occurred between colleagues or other employees. Often the interviewed adults got up early in the morning being irritable without knowing what caused that. Many of the respondents mentioned that they felt that 2-3 times. It was observed that the participants of the interview suffered from volatile behaviours. Some respondents realized that trying to relieve stress they were trying to calm down, contemplate over all decisions or even engage in other activities. Meanwhile, others mentioned that the right way for them to get rid of stress or tension was to snack during work or chew gum ("To avoid stress during work, I snack because it seems that when I chew something, I stave off my problems, and it helps", Viktorija). It is known that chewing or eating during stress is a psychological illness. Stress forces us to activate all our muscle groups and for this reason everything is done faster - moving, swallowing, chewing, etc., which further increases tension and anxiety.

The subjects had to answer how they evaluated their health. Respondents admitted having overweight, others said they suffered from stomach problems, bloating, or just overeating ("I have stomach problems, I like to eat, I really like to live with my belly and its problems", Julius). Besides, there were interviewees who simply did not want to talk about their health status believing it to be confidential information. One man admitted having problems with his heart, he had had cardiovascular diseases and even a heart attack (I am a cardiac patient and I had a heart attack, Gintas). It was discovered that after a working day, the subjects felt back pain and some of them even hada spinal hernia, and they had been suffering from it for a long time ("I have a spinal hernia that is being treated for a few years, I need surgery but I still hesitate...", Auksè). The summarized assessment of physical and psychological health of the research participants is presented in Table 2 .

Summarizing the assessment of the psychological and physical health of the subjects, it is observed that the subjects usually experience bad mood and stress during work, under stressed 
Table 2. Physical and psychological health of research participants

\begin{tabular}{|c|c|c|}
\hline Categories & Subcategories & Examples from interview transcripts \\
\hline \multirow{3}{*}{$\begin{array}{l}\text { Psychological } \\
\text { health }\end{array}$} & $\begin{array}{l}\text { Mood changes } \\
\text { and volatility }\end{array}$ & $\begin{array}{l}\text { The mood is bad when I fail or get angry with someone, I think 1-2 times a week... } \\
\text { (Audronè). } \\
<\ldots>\text { I am tormented by my bad mood in winter and autumn (Ksenija). } \\
\text { The bad mood often presses me 2-3 times a week (Gintas). }\end{array}$ \\
\hline & $\begin{array}{l}\text { Experiencing } \\
\text { stress }\end{array}$ & $\begin{array}{l}<\ldots>\text { stress is inevitable, especially at work (Lukas). } \\
\text { I lack patience when working with students, }<\ldots>\text {, sometimes I am stressed (Aušrinè). }\end{array}$ \\
\hline & Insomnia & $\begin{array}{l}<\ldots>\text { not always I manage to go to sleep, sometimes I go to sleep at about } 2 \text { a.m. and then } \\
7 \text { am I go to work (Viktorija). } \\
\text { If I exercised after work, I wouldn't sleep at all at night because now I can hardly go to } \\
\text { sleep early (Julius). } \\
<\ldots>\text { I lie down in bed, but I can't sleep for a while (Laima). }\end{array}$ \\
\hline \multirow{4}{*}{$\begin{array}{l}\text { Physical } \\
\text { health }\end{array}$} & Overweight & $\begin{array}{l}\text { Genetically inherited reflex. Overweight from childhood (Agnè). } \\
<\ldots>\text { I noticed that I no longer could use my clothes I was wearing last year. (Audronė) } \\
\text { I have overweight that limits my physical activity (Giedrius). }\end{array}$ \\
\hline & $\begin{array}{l}\text { Gastrointestinal } \\
\text { diseases }\end{array}$ & $\begin{array}{l}\text { I have stomach problems }<\ldots>\text { (Julius). } \\
\text { High cholesterol levels ... (Ksenija). }\end{array}$ \\
\hline & $\begin{array}{l}\text { Cardiovascular } \\
\text { diseases }\end{array}$ & $<\ldots>i$ am a cardiac patient, I had a heart attack (Gintas). \\
\hline & Backache & $\begin{array}{l}<\ldots>\text { after work I feel low back pain; I don't even know, maybe because of sitting too } \\
\text { much ... (Aušrinè). } \\
\text { I have a spinal hernia that I treat for several years, }<\ldots>\text { I need a surgery (Auksè). }\end{array}$ \\
\hline
\end{tabular}

working conditions; and overweight or backache may affect their physical activity.

Activity areas of sedentary adults. The study aimed at analysing key activities of the research participants that can be classified as physically active and passive. Most of the interviewees admitted that they spent their leisure time passively, that is, they read books, worked at home using their smart devices (I eat, watch TV, sit on Facebook and read news online, Laima). The results showed that family people had to take care of their children when they returned home, pay attention to them, play games with them, cook, or engage in other household activities (We are often at home with our family, we cook meals and spend time together playing board games, Ksenija). Meanwhile, other interviewees mentioned that they had to do the work they did not manage to do at the university and they had to prepare for the next day's lectures, check students' independent work or tests (We eat and then I go to check students' assignments or read the materials for my new lectures, Giedrius).

Very few choose to take a walk in the city park or engage in outdoor activities like cycling or fishing. Respondents mentioned that they choose to travel abroad in their free time. They could be attributed to active people as sightseeing includes a lot of walking (Every year we travel, we want to get to know different cultures and customs, Evelina). Table 3 summarizes the non-work activity of adults.

Summarizing the activities of the respondents we assume that people are physically active very rarely, usually only in their leisure time. At home physical activity is also diminished as most sedentary adults continue to work and others spend time watching TV, sitting at the computer or reading books (Table 3 ).

Evaluation of physical activity of sedentary adults. Analysing the respondents' responses on the benefits of physical activity, it was found out that people who had to engage in physical activity felt more energetic and even more lively the next day (Although I do little sports, but I will not lie, health benefits really are obvious - the next day I feel really more lively, Giedrius).

As for the emotional state, the results are not surprising, as everyone unequivocally agreed that sport had a positive effect on our brain, it allows us to forget our bad thoughts and relax (Active workouts allow you to forget the difficulties, various problems and they also allow you to relax emotionally, Agnè). However, there were also respondents who were overwhelmed by sports and 
Table 3. Activities od sedentary adults outside working hours

\begin{tabular}{|c|c|c|}
\hline Categories & Subcategories & Examples from interview transcripts \\
\hline \multirow{3}{*}{$\begin{array}{l}\text { Physically active } \\
\text { activities }\end{array}$} & $\begin{array}{l}\text { Traveling on } \\
\text { holiday }\end{array}$ & $\begin{array}{l}<\ldots>\text { we are planning a vacation with my husband to visit several countries } \\
\text { (Audrone). } \\
<\ldots>\text { we travel every year; we want to get to know different cultures and customs } \\
\text { (Evelina). }\end{array}$ \\
\hline & Cooking & $\begin{array}{l}\text { We are often at home with the family; we cook meals and spend time together play- } \\
\text { ing board games (Ksenija). } \\
<\ldots>\text { I cook for the whole family after work (Viktorija). }\end{array}$ \\
\hline & $\begin{array}{l}\text { Outdoor activities } \\
\text { in nature }\end{array}$ & $\begin{array}{l}<\ldots>\text { fishing has already been a favourite activity from the past, sometimes even } \\
\text { now we go fishing to catch some fish with my father (Julius). } \\
<\ldots>\text { hiking, and on summer evenings we go for a walk with my husband (Evelina). } \\
<\ldots>\text { if it's warm outside, we go for a walk (Ksenija). } \\
<\ldots>\text { During the summer our family goes to Druskininkai for a walk (Gintas). }\end{array}$ \\
\hline \multirow{3}{*}{$\begin{array}{l}\text { Physically passive } \\
\text { activities }\end{array}$} & $\begin{array}{l}\text { Sedentary work at } \\
\text { home }\end{array}$ & $\begin{array}{l}<\ldots>\text { I continue to work and prepare for lectures (Giedrius). } \\
\text { We eat and I go to check students' assignments or read the materials for a new } \\
\text { lecture (Giedrius). } \\
<\ldots>\text { I study and write my PhD dissertation (Ksenija). } \\
\text { I help children prepare lessons and later sit down to my own work (Auksè). }\end{array}$ \\
\hline & $\begin{array}{l}\text { Time fat the smart } \\
\text { devices }\end{array}$ & $\begin{array}{l}<\ldots>\text { I eat, watch } T V,<\ldots>\text {, I sit on facebook and read news online (Laima). } \\
<\ldots>\text { nothing special }<\ldots>\text { - watch } T V(\text { Aušrine). } \\
<\ldots>\text { when I come home I turn on the TV, I do not like silence, so something has to } \\
\text { go for the background, and later, when I have free time, I read Delfi and } 15 \text { min. } \\
\text { (Audrone). } \\
<\ldots>\text { I cannot survive without a phone; I communicate with friends and colleagues } \\
\text { through social networks (Lukas). } \\
<\ldots>\text { I watch sports on TV, especially basketball (Gintas). } \\
\text { I am often tired after a hard day's work, so I spend my time with my family, watch- } \\
\text { ing television and the I go to sleep (Julius). }\end{array}$ \\
\hline & Reading books & $\begin{array}{l}<\ldots>\text { if I have nothing to do, I read books (Auksė). } \\
<\ldots>\text { I read books - for me it is like meditation, I relax from my daily routine } \\
\text { (Evelina). } \\
<\ldots>\text { I spend my free time at home reading books (Viktorija). }\end{array}$ \\
\hline
\end{tabular}

therefore did not feel any improvement (If I do not overstrain, my emotional health is good, Ksenija).

During the interviews it turned out that social health was important for the subjects. Adults responded that they did not want to do sports all by themselves as it was sad and thus they lacked motivation (It is always more fun to work-out with a partner than alone, and it is more motivating, Laima). Others said that in the group of people it is always more fun to do sports and there is a social reason to get engaged in sports because others do that (I like to play volleyball in a group of friends because it is team sport, people in the group have always more fun than being alone. There is a social reason to encourage a person to do sport because others are so athletic ..., Evelina).

During the study, adults not only appreciated the benefits of well-being, emotional and social health, but also mentioned that they were noticing changes in the body. They pointed out that the body became firmer, muscles became more visible, and they could even lose weight (If I do some exercise or walk more, the weight diminishes, Gintas).

Assessment of physical activity and health is provided in Table 4.

The responses received show that many of the respondents appreciate the benefits of physical activity for well-being and emotional health. Respondents also notice body changes that make them happy.

Effect of working conditions on physical activity in sedentary adults. The study aimed at assessing the impact of working conditions on the physical activity of sedentary adults. Research participants said they were working in a friendly team and did not have anything to complain about although they had to work overtime (I started 
Table 4. Assessment of physical activity of sedentary adults

\begin{tabular}{|c|c|c|}
\hline Categories & Subcategories & Examples from interview transcripts \\
\hline \multirow{3}{*}{ Health benefits } & Well-being & $\begin{array}{l}<\ldots>\text { obviously, after exercise I feel much recovered, lively and, of course, most energetic, } \\
\text { I get a good energizer for the whole day (Agnè). } \\
<\ldots>\text { I am happy with myself for my well-being, it seems that I have done a good job for } \\
\text { myself (Evelina). }\end{array}$ \\
\hline & $\begin{array}{l}\text { Emotional } \\
\text { health }\end{array}$ & $\begin{array}{l}<\ldots>\text { before exercising I feel as usual, but after it - emotionally recovered (Julius). } \\
<\ldots>\text { active workouts allow you to forget your difficulties, various problems and allow } \\
\text { you to relax emotionally (Agne). }\end{array}$ \\
\hline & Social health & $\begin{array}{l}<\ldots>\text { I like to play volleyball in a group of friends because it is a team sport; people in } \\
\text { the group always have more fun than being alone. There is a social reason to encourage } \\
\text { a person to do sport because others are so athletic (Evelina). } \\
<\ldots>\text { It is always more fun to work-out with a partner than alone, and it is more motivat- } \\
\text { ing (Laima). }\end{array}$ \\
\hline $\begin{array}{l}\text { Changes in body } \\
\text { composition }\end{array}$ & Appearance & $\begin{array}{l}\text { After training in the gym I noticed that my body became firmer (Evelina). } \\
\text { After exercise the muscles are bigger, and you can see the abdomen press (Aušrinè). }\end{array}$ \\
\hline
\end{tabular}

working quite recently, I am happy so far though I have to work overtime, Audronè). Meanwhile, others are not satisfied with the hard workload because they feel tired and not energetic in the evening (I have a lot of work, sometimes I come back late in the evening, I really feel great fatigue, Viktorija). Such factors not only damage health but also promote physical inactivity.

Then questions were asked about hours of rest in order to find out whether adults were passive or active during work or during rest or lunch breaks. The vast majority said that the rest area was passive, everyone was sitting and drinking coffee, some respondents said they would go out for a walk in good weather (If it is warm, I like to go out for a walk during the break, Evelina). Table 5 provides systematic data on the impact of working conditions on sedentary adult activity.

Summarizing the data in Table 5, it can be assumed that adults at work are physically inactive, passive, little moving because of the nature of the sitting and / or standing job. During their rest time, they rarely go out for a walk.

Internal and external causes of insufficient physical activity. After analysing the responses of the interviewees, two causes for insufficient physical activity were distinguished - internal and external. It was observed that internal causes were not only a lack of time, but also a lack of external and internal motivation (To tell the truth, I have no

Table 5. Effect of working conditions on physical activity of sedentary adults

\begin{tabular}{|c|c|c|}
\hline Categories & Subcategories & Examples from interview transcripts \\
\hline \multirow[b]{2}{*}{$\begin{array}{l}\text { Working } \\
\text { environment and } \\
\text { conditions }\end{array}$} & Positive aspects & $\begin{array}{l}<\ldots>\text { I am partly satisfied with my working conditions, we are a friendly team (Viktorija). } \\
<\ldots>\text { I am happy with the working conditions, so I do not have anything to complain } \\
\text { about (Aukse). }\end{array}$ \\
\hline & Negative aspects & $\begin{array}{l}<\ldots>\text { I would like a lifting table (Laima). } \\
<\ldots>\text { I have to work overtime, which is not acceptable to me (Lukas). } \\
\text { I have a lot of work, sometimes I come back late in the evening, I really feel great fatigue } \\
\text { (Evelina). } \\
\text { I would like to reduce the number of lectures because I have no time for myself, but now } \\
\text { the employer cannot give me such conditions (Gintas). } \\
<\ldots>\text { Currently, the University lacks staff, so I work longer than I have to (Ksenija). }\end{array}$ \\
\hline \multirow[b]{2}{*}{ Rest area } & Positive aspects & $\begin{array}{l}<\ldots>\text { if it is warm, I like to go for a walk during the break (Evelina). } \\
\text { We take advantage of rest, }<\ldots>\text {, and we go to the cafe with colleagues (Laima). }\end{array}$ \\
\hline & Negative aspects & $\begin{array}{l}\text { Tight work with students, I don't have time to go to the lounge (Auksè). } \\
<\ldots>\text { rest area is passive - we sit, drink coffee ... (Agnè). } \\
\text { There is nothing to do during the rest break ... - the administration could set up an ac- } \\
\text { tive space (Lukas). }\end{array}$ \\
\hline
\end{tabular}


motivation to do sport, it's hard to make myself to go to the gym, Julius).

Research participants said they had no time to do sports after returning from work because they had to continue to work on the computer or simply they did not have the willpower to engage in physical activity. Laziness is the main barrier to physical activity. Often, adults do not have any motivation to do sports; they prefer a passive way of spending leisure time at TV screens. Also, some feel antipathy for sport and do not like this activity. They argue that they should rather engage in other activities such as reading books. Some respondents said they could not do sports due to health problems such as backache or overweight. Both men and women felt lonely, some of them were divorced ( $I$ don't have company, I am divorced, Laima). It is noteworthy that the senior respondents thought that age was a hindrance to sports, they felt different than before, and therefore they urged younger people to be more physically active. Table 6 summarizes the causes of the respondents' physical inactivity.

As for external causes, it was observed that fatigue and workload had a significant impact on the subjects' physical activity. Respondents said they did not want anything as they were tired after work, only rest at home with their family. They admit that working with students consumes a lot of energy and strength, so fatigue prevents them from being physically active. Very few adults choose a bicycle as a vehicle to get to work because poor weather conditions can prevent riding a bike.

The adults also pointed out the financial situation as one of the reasons for the lack of physical activity because the salaries were not high; others said they did not find a suitable fitness club according to their income. The subjects were influenced by family and household as well. Most of the time is spent on children, cooking or housework. These aforementioned factors limited their physical activity. The causes of physical inactivity are detailed in Table 7.

Summarizing the causes of physical inactivity, it can be suggested that internal causes are related to internal human beliefs, and external causes - to the environment. It can therefore be concluded that internal causes are more difficult to have removed than the external ones. Many internal reasons are influenced by the inner attitudes that hinder the change of lifestyle. External causes of physical inactivity can be overcome easily if the person is highly motivated and wants to engage in physical activity.

Table 6. Internal causes of physical inactivity

\begin{tabular}{|c|c|}
\hline Subcategories & Examples from transcripts \\
\hline Lack of time & $\begin{array}{l}\text { I don't have tome }<\ldots . .>\text {, when I come back from work, I want to rest (Agnè). } \\
<\ldots>\text { because of the heavy workload and I am still writing my PhD dissertation, so I have no time at all } \\
\text { (Audrone). } \\
\text { I have no time and desire (Viktorija). } \\
\text { Lack of time }<\ldots>\text {, when I come back after work, I have to prepare for the lectures, to check the students, } \\
\text { works (Laima). }\end{array}$ \\
\hline Lack of motivation & $\begin{array}{l}<\ldots>\text { I am just lazy to do sport; I can't do anything (Aušrinė). } \\
<\ldots>\text { I don't even know where to find motivation for sport, it seems and I want but I am lazy, that's all } \\
\ldots \text { (Auksè). } \\
<\ldots>\text { it's hard to start to move (Evelina). }\end{array}$ \\
\hline Antipathy for sport & $\begin{array}{l}\text { I am inactive from my childhood }<\ldots>\text {, physical education was the course I hated most of all }<\ldots>\text { my } \\
\text { grade average was not bad, but physical education was only satisfactory (Ksenija). } \\
\text { I hate sport ... > - I'd better watch TV or read a book at home (Giedrius). }\end{array}$ \\
\hline Health problems & $\begin{array}{l}\text { I don't really want to talk }<\ldots>\text {, I have health problems that restrict my physical activity (Gintas). } \\
<\ldots>\text { sedentary work causes backache (Agnè). } \\
\text { After exercise I feel tired and my heart rate increases, I don't know if it is good (Viktorija). } \\
<\ldots>\text { it is difficult to admit, but I have overweight that prevents me from exercising (Audronè). }\end{array}$ \\
\hline $\begin{array}{l}\text { The feeling of } \\
\text { loneliness }\end{array}$ & $\begin{array}{l}\text { I don't want to exercise alone and I don't want to commit to a company (Lukas). } \\
\text { I don't have anybody to exercise with, I am divorced }<\ldots>\text { (Laima). }\end{array}$ \\
\hline Age & $\begin{array}{l}<\ldots>\text { let the youth workout, it is not my first youth (Viktorija). } \\
<\ldots>\text { neither will I be an athlete nor my age is good for exercising (Agnè). } \\
\text { You must be kidding - I am already } 49 \text {... (Gintas). }\end{array}$ \\
\hline
\end{tabular}


Table 7. External causes of physical inactivity

\begin{tabular}{|c|c|}
\hline Subcategories & Examples form transcripts \\
\hline $\begin{array}{l}\text { Fatigue due to high } \\
\text { workload }\end{array}$ & $\begin{array}{l}\text { When I'm back after work, I don't want anything, just rest (Gintas). } \\
\text { I work with students, and it looks like I'm exhausting my energy }<\ldots>\text { and I still have to finish my work } \\
\text { at home (Aukse). } \\
\text { I have to work on the computer after work (Aušrinè). }\end{array}$ \\
\hline Weather conditions & $\begin{array}{l}\text { Sometimes the weather conditions were frightening and we didn't want to leave home (Ksenija). } \\
<\ldots>\text { in bad weather, there is no desire to do sports (Lukas). } \\
<\ldots>\text { if it rains, I drive more often (Giedrius). }\end{array}$ \\
\hline Financial situation & $\begin{array}{l}<\ldots>\text { teachers do not earn too much to be able to keep the family and do sports (Viktorija). } \\
<\ldots>\text { sport clubs have very high competition, but the prices are inadequate (Agne). }\end{array}$ \\
\hline Family & $\begin{array}{l}<\ldots>\text { after returning home, I have to communicate with my family, to play games with children (Lukas). } \\
<\ldots .>\text { they are still small, they need my attention (Evelina). } \\
\text { After work day there is no time to go in for sports, I think my children need me, they miss me all day } \\
\text { (Ksenija). } \\
<_{\ldots}>\text { I cannot afford such pleasure - to leave home for at least several hours, I have little children } \\
\text { (Aušrine). }\end{array}$ \\
\hline Housework & $\begin{array}{l}\text { After work at home, other chores are waiting for me - cooking ... (Agnè). } \\
<\ldots>\text { I watch TV and tidy my rooms }<\ldots>- \text { sports only at weekends (Laima). } \\
\text { After work I am really active: I eat, read a book, and spend time with my family (Evelina). } \\
<\ldots>\text { sometimes I want to do something more, but sooner or I have to care about myself and my family } \\
\text { (Auksè). }\end{array}$ \\
\hline
\end{tabular}

\section{DISCUSSION}

The study sought to understand the main causes of physical inactivity in adults that prevent their physical activity. Also we wanted to find out what activities respondents were engaged in during their working hours, and how they spent the rest of their day or leisure time. We aimed at investigating whether working conditions and workload affected the physical activity and health of the research participants. The perception of the benefits of physical activity for the well-being, emotional and social state of the subjects was investigated as well. Adults had to indicate how they evaluated their psychological and physical health.

The results of the study revealed that after returning from work some adults continued to work as tutors and teachers, they checked student assignments and tests, constructed new tests, collected materials for lectures. Others sat passively watching TV or surfing the web on social sites. There were also those who wanted to spend time for themselves - to read books, as it helps to get away from family problems and not to think about upcoming jobs. Research by other scientists shows that younger people are more mobile and thus more physically active than adults (Molanorouzi, Khoo, \& Morris, 2015).
Not all the respondents were satisfied with their working conditions. They mentioned that they would be happy to have a lifting table or they would like to reduce the duration of their work because after a long working day they felt tired and did not want to do anything and only passively spend the evening. Some of them had to work longer hours. They explained that they were working overtime due to a reduced number of employees. Therefore, working conditions may not only have a negative impact on physical activity but also on health. As a result of the extraordinary impact of work on human life, health and society, work values are considered to be fundamental, because the health of the worker is the most important aspect to ensure the quality of the work performed (Clark, Kolbe-Alexander, Duncan, \& Brown, 2017). The study showed that non-standard work schedules were associated with adverse health effects. Working overtime increases fatigue, sleep disturbances, and the risk of cardiovascular diseases (Merkus, Holte, Huysmans, van Mechelen, \& van der Beek, 2015). Rich and full-fledged recreation is also important in adult life. Research participants revealed the fact that the lounge was meant for passive rest, most often it was used for drinking coffee and communicating with 
colleagues. Others would like to have an active rest during the break and offered the employer to install areas where they could play table tennis or similar games. In the clinical population, human health has been determined to depend on the duration of sedentary activity, and it is therefore necessary to move or to take a walk after a long period of work. Physical activity has been shown to be associated with various positive health outcomes, including better mental health, and to reduce the incidence of cardiovascular diseases. It has also been found that physical activity improves health-related quality of life (Kolt et al., 2017).

The participants of the study indicated the benefits of physical activity to health, emotional well-being and appearance. Respondents believe that physical activity provides more energy, and the next day they feel like having done a good job for themselves. Researchers also claim that physical activity can prolong life expectancy and quality. Research has shown that regular physical activity is associated with a reduction in premature death and chronic diseases such as coronary heart disease, stroke, type 2 diabetes, depression and some types of cancer. Regular exercise increases the average life expectancy as physical activity slows down the development of chronic diseases (Paul et al., 2015). Speaking of the benefits to emotional well-being, the subjects revealed that they improved their mood when exercising, feel as usual before sports, and after exercising they were emotionally recovering. Active workouts allow them to forget the difficulties and various problems. Research data show a link between physical activity and psychological wellbeing (Vancampfort et al., 2017). Physical activity has been shown to significantly reduce the risk of depression and mental disorders in healthy adults or those with chronic diseases and to reduce the symptoms of people with mental disorders. These data show that physical activity is associated with reduced symptoms and frequency of mental illnesses and increased self-confidence (Bernard et al., 2018). Respondents assured that social health was no less important as they could get more motivation to exercise while exercising with friends or partners, and notice mistakes often made or learn how to do the exercises correctly. Research participants say they like to play a variety of team games in a group of friends because team sports promote social life and encourage getting involved in sports. Research shows that social support and sustainable supportive relationships could help to make acquaintances, and physical activity in groups has the added value of social support that can encourage active movement and social identity (Quirk, Crank, Harrop, Hock, \& Copeland, 2017). In the opinion of the participants, appearance also contributes to changes in health, it is said that the body becomes firmer due to exercise, the body composition indicators also show changes, for example, in the muscle mass. Respondents noticed that even low physical activity could reduce body weight, and if they were more active, they could see greater changes in their appearance. Research suggests that sedentary lifestyle leads to weight gain while reducing muscle mass. However, regular physical activity prevents obesity and is a natural tool for reducing its prevalence. Also, exercising people do not just lose unnecessary kilograms, but also radically change their body appearance (Sofková \& Přidalová, 2015). Research has shown that resistance exercises have a positive effect on reducing weight in people who are overweight or obese (Sigal et al., 2014).

The analysis of the psychological health of subjects showed that people in bad mood tried to snack during work and to calm down in this way, and then to continue their unfinished work. It has been observed that stress usually arises from other people's poor performance and difficulties. Research shows that adults who poorly appreciate their psychological health struggle to cope with the difficulties they experience (Kaseva et al., 2016). It has been found that physical activity reduces the development of depression, makes people feel better and controls their emotional state. Therefore, people feel more satisfied with life and happier. Most importantly, physical work can effectively improve work capacity and productivity. In terms of physical health, respondents experienced health problems such as overweight, backache, stomach and intestinal problems, and cardiovascular diseases. Preventing and controlling lifestyle-related risk factors can reduce the frequency of vascular and metabolic diseases and other disability conditions (Wang, Li, Jones, Bodner, \& Dean, 2019).

Despite all the recommendations and the perceived health benefits of physical activity, the physical activity of adults is decreasing. Respondents considered the lack of time to be one of the reasons that hinder exercising, as there is other work that needs to be done for the next day after returning home, so there is not enough time for physical activity. Time constraints are one of the most common obstacles to being physically active, but it has been shown that shorter physical activity (i.e. $\leq 10$ minutes) accumulated per day can bring similar health benefits (Kolt et al., 2017). The World Health Organization 
suggests that adults take part in a weekly exercise of at least 150 minutes of moderate aerobic exercise and at least 75 minutes of intense aerobic exercise, taking increasingly reducing physical activity into account (WHO, 2016). Our research participants said they could not engage in physical activity due to lack of motivation or lack of interest in sports and they chose passive leisure time spending it on smart devices. Internal motivation is identified as one of the most important factors for positive, meaningful and long-term changes in physical activity behaviour (Santos, Ball, Crawford, \& Teixeira, 2016). Better health increases self-confidence and improves selfesteem (Mathews et al., 2016).

The external causes of physical inactivity were fatigue, workload, weather conditions, financial situation, family concerns, and household. With the intensification of work and life rhythm, fatigue and workload are the main causes of physical inactivity; respondents say they have no strength for exercising after returning home. Research shows that people often use their positive emotional resources over time; they experience stress and can hardly overcome its consequences. With such a prolonged state, full physical and mental exhaustion is possible, which affects a person's motivation, attitudes and behaviour (Kavaliauskienè \& Balčiūnaitè, 2015). The financial situation is also one of the reasons for inactivity. Individuals with lower economic incomes usually overestimate personal barriers, for example, they say they have no financial resources to buy a sports club membership subscription, or they are unable to select a sports venue according to their needs (Herazo-Beltrán et al., 2017). It has been found that women living in socially disadvantaged areas have a higher risk of physical inactivity regardless of their individual social and economic circumstances, which may lead to greater health and social inequalities (Santos et al., 2016). Family concerns and household were identified as one of the reasons for lack of physical activity. Research participants said they had housework when they returned home. They had more family responsibilities such as cooking, playing with children or helping them do their homework. Therefore, these factors are thought to limit the physical activity of adults because of their high occupancy at home. Research testifies that due to their lifestyle problems associated with family responsibilities women are under heavy strain that promotes lack of physical activity. Women are more likely to be tired and have no time, partly because of their marital status, in contrast to men (Santos et al., 2016). This problem is relevant up to nowadays because we need to take care of our health in advance to ensure proper aging. It is important to carry out more similar research to identify the causes of increasing physical inactivity and to introduce activities that would encourage physical activity so that no causes could interfere with it.

The problem is that knowledge of the consequences does not help to prevent the social welfare from being hindered by external and internal barriers. Personal adaptive and thinking powers also provide limitations and uncertainty for this phenomenon.

\section{CONCLUSIONS}

1. The results of the qualitative study show that inadequately physically active adults have physical health problems such as overweight, gastrointestinal disorders of cardiovascular diseases as well as backache. Psychological ailments are constant changes of mood, frequent stress and insomnia. These listed disorders are the most common consequences of physical inactivity.

2. The non-working activities of adults studied were passive, such as work at home, reading books and time on smart devices, and active holidays, cooking, playing games with children, and activities in nature. Although there are more active activities, most of them are in their leisure time when they have free time. Physically active activities of adults do not fully comply with the proposed minimal recommendations.

3. Research participants positively evaluated the benefits of physical activity if their physical activity did not exceed their physical fitness levels. After exercising, they feel physically stronger, more energetic and more relaxed. Also, physical activity has a positive effect on emotions: they faster forget their bad thoughts and experience more positive emotions. Adults also notice changes in appearance, their gradually changing bodies. However, if they are overwhelmed with exercising, they are fatigued and feel muscle pain, which lowers motivation to exercise.

4. Internal causes of physical inactivity of the subjects include lack of time, lack of motivation, antipathy for sport, health problems, feeling of loneliness and their age. External causes are fatigue and workload, weather conditions, financial situation, family concerns and household. There are more internal causes than external, and it is more difficult to overcome them than the external ones. 


\section{REFERENCES}

Bernard, P., Doré, I., Romain, A. J., Hains-Monfette, G., Kingsbury, C., \& Sabiston, C. (2018). Dose response association of objective physical activity with mental health in a representative national sample of adults: A cross-sectional study. PloS One, 13(10), e0204682. doi: 10.1371/journal.pone.0204682

Caron, A., Ayala, A., Damián, J., Rodriguez-Blazquez, C., Almazán, J., Castellote, J. M., ... \& de Pedro, J. (2017). Physical activity, body functions and disability among middle-aged and older Spanish adults. BMC Geriatrics, 17(1), 150. doi: 10.1186/s12877-017-0551-z

Clark, B., Kolbe-Alexander, T., Duncan, M., \& Brown, W. (2017). Sitting time, physical activity and sleep by work type and pattern - The Australian Longitudinal Study on Women's Health. International Journal of Environmental Research and Public Health, 14(3), 290.

Duriau, V. J., Reger, R. K., \& Pfarrer, M. D. (2007). A content analysis of the content analysis literature in organization studies: Research themes, data sources, and methodological refinements. Organizational Research Methods, 10(1), 5-34. https://doi.org/10.1177\%2F1094428106289252

Francis, J. J., Johnston, M., Robertson, C., Glidewell, L., Entwistle, V., Eccles, M. P., \& Grimshaw, J. M. (2010). What is an adequate sample size? Operationalising data saturation for theory-based interview studies. Psychology and Health, 25(10), 1229-1245. https://doi. org/10.1080/08870440903194015

Herazo-Beltrán, Y., Pinillos, Y., Vidarte, J., Crissien, E., Suarez, D., \& García, R. (2017). Predictors of perceived barriers to physical activity in the general adult population: A cross-sectional study. Brazilian Journal of Physical Therapy, 21(1), 44-50.

Kaseva, K., Rosenström, T., Hintsa, T., Pulkki-Råback, L., Tammelin, T., Lipsanen, J., ... \& Hirvensalo, M. (2016). Trajectories of physical activity predict the onset of depressive symptoms but not their progression: A prospective cohort study. Journal of Sports Medicine, 2016, 89475. doi: 10.1155/2016/8947375

Kavaliauskienė, V., \& Balčiūnaitè, R. (2015). Profesinis perdegimas ir jo raiška socialinio darbo profesionalizacijos kontekste. Tiltai, 69(4), 17-36.

Kolt, G. S., George, E. S., Rebar, A. L., Duncan, M. J., Vandelanotte, C., Caperchione, C. M., ... \& Mawella, N. R. (2017). Associations between quality of life and duration and frequency of physical activity and sedentary behaviour: Baseline findings from the WALK 2.0 randomised controlled trial. PloS one, 12(6), e0180072. doi: 10.1371/journal.pone.0180072

Maheri, A., Asnaashari, M., Joveini, H., Tol, A., Firouzian, A. A., \& Rohban, A. (2017). The impact of educational intervention on physical activity, nutrition and laboratory parameters in type II diabetic patients. Electronic Physician, 9(4), 4207. https://doi.org/10.19082/4207

Merkus, S. L., Holte, K. A., Huysmans, M. A., van Mechelen, W., \& van der Beek, A. J. (2015). Nonstandard working schedules and health: The systematic search for a comprehensive model. BMC Public Health, 15(1), 1084. doi: 10.1186/s12889-015-2407-9

Molanorouzi, K., Khoo, S., \& Morris, T. (2015). Motives for adult participation in physical activity: Type of activity, age, and gender. BMC Public Health, 15(1), 66. https:// doi.org/10.1186/s12889-015-1429-7

Noble, H., \& Mitchell, G. (2016). What is grounded theory? Evidence-Based Nursing, 19, 34-35. http://dx.doi. org/10.1136/eb-2016-102306

Patton, M. Q. (2001). Qualitative Research and Evaluation Methods (2nd Edition). Thousand oaks, CA: Sage Publications.

Paul, P., Carlson, S. A., Carroll, D. D., Berrigan, D., \& Fulton, J. E. (2015). Walking for transportation and leisure among US adults - National Health Interview Survey 2010. Journal of Physical Activity and Health, 12(Suppl. 1), S62-69. doi: 10.1123/jpah.2013-0519

Quirk, H., Crank, H., Harrop, D., Hock, E., \& Copeland, R. (2017). Understanding the experience of initiating community-based physical activity and social support by people with serious mental illness: A systematic review using a meta-ethnographic approach. Systematic Reviews, 6(1), 214. doi: 10.1186/s13643-017-0596-2

Santos, I., Ball, K., Crawford, D., \& Teixeira, P. J. (2016). Motivation and barriers for leisure-time physical activity in socioeconomically disadvantaged women. PloS One, 11(1), e0147735. doi: 10.1371/journal.pone.0147735

Sofková, T., \& Přidalová, M. (2015). Somatic characteristics in relation to meeting recommended physical activity in overweight and obese women aged 30-60 years. Acta Gymnica, 45(3), 121-128. doi: 10.5507/ag.2015.013

Thanamee, S., Pinyopornpanish, K., Wattanapisit, A., Suerungruang, S., Thaikla, K., Jiraporncharoen, W., \& Angkurawaranon, C. (2017). A population-based survey on physical inactivity and leisure time physical activity among adults in Chiang Mai, Thailand, 2014. Archives of Public Health, 75(1), 41. doi: 10.1186/s13690-017-0210-z Vancampfort, D., Van Damme, T., Probst, M., Firth, J., Stubbs, B., Basangwa, D., \& Mugisha, J. (2017). Physical activity is associated with the physical, psychological, social and environmental quality of life in people with mental health problems in a low resource setting. Psychiatry Research, 258, 250-254.

Wang, P., Li, Z., Jones, A., Bodner, M. E., \& Dean, E. (2019). Discordance between lifestyle-related health behaviors and beliefs of urban mainland Chinese: A questionnaire study with implications for targeting health education. AIMS Public Health, 6(1), 49. doi: 10.3934/ publichealth.2019.1.49

World Health Organization. (2016). Physical activity and older adults. Retrieved from http://www.who.int/ dietphysicalactivity/factsheet_olderadults/en/ 